РОЗВИТОК ТВОРЧОЇ ІНДИВІДУАЛЬНОСТІ СТУДЕНТА ЗАСОБАМИ ХОРЕОГРАФІЧНОГО МИСТЕЦТВА

\title{
DEVELOPMENT OF CREATIVE INDIVIDUALITY OF STUDENT BY MEANS OF CHOREOGRAPHIC ART
}

\begin{abstract}
Пріоритетним завданням вищих навчальних закладів педагогічного спрямування стає підготовка вчителя нової генерації, котрий уособлює яскраву творчу індивідуальність, здатну забезпечити максимальну реалізацію творчого потенціалу вихованця, а це характерно для вчителів мистецьких дисциплін, зокрема вчителів хореографрії. Розвиток творчої індивідуальності практично неможливий без самої творчості. Для того, щоб людина набула певних навичок, ссрормувала в собі певні якості, набула певних практичних умінь, необхідна постійна і систематична творча діяльність.
\end{abstract}

у статті розкрито форми роботи з майбутніми вчителями хореографіії, які містять у собі елемент творчості та спрямовані на постійний розвиток їх творчої індивідуальності, розкриття їх творчого потенціалу та фрормування справжнього творчого вчителя засобами практичної діяльності.

Ефективним засобом реалізації цього завдання правомірно вважається хореографрічне мистецтво, адже в хореограсрії франтазія, різноманітність, непередбачуваність відіграють важливу роль, оскільки кожне нове виконання танцю, створення нових елементів лексики та фрігур вимагає імпровізаційності, творчості, свіжості. Хореографрічне мистецтво - це мистецтво пластичне, де матеріалом слугує саме людське тіло, яке, ніби оживлена музикою скульптура, естетично довершено втілює у своїх граційних рухах гармонію тіла й душі людини, їі зовнішню та внутрішню красу. На основі аналізу психолого-педагогічноі мистецтвознавчої літератури розкривається поняття і визначається сутність дефініцій танцю, що дозволило визначити його як просторово-часовий інтегрований вид мистецтва, в якому художні образи створюються за допомогою естетично значущих, музично організованих, ритмічно змінюваних рухів і поз людського тіла. Формування в танцюриста своєї танцювальної мови відбувається в культурному контекcmi, необхідно, щоб створення танцю не обмежувалося лише вільною імпровізацією, спонтанним втіленням думок і почуттів у танцювальних рухах. Велике значення має виховання культури танцювальних рухів, що уможливлюється шляхом творчого опанування культурного досвіду людства у галузі хореографpii.
Ключові слова: творчість, хореографрічне мистецтво, танець, творча індивідуальність, особистість.

The priority of higher educational institutions of pedagogical direction is the preparation of a new generation teacher who embodies a bright creative personality, capable of ensuring the maximum realization of the creative potential of the pupil, and this is characteristic of teachers of artistic disciplines, in particular teachers of choreography. The development of creative individuality is practically impossible without the creativity itself. In order for a person to acquire certain skills, to form certain qualities, to acquire certain practical skills, constant and systematic creative activity is required.

The article describes forms of work with future choreography teachers, which include an element of creativity and are aimed at the constant development of their creative personality, the disclosure of their creative potential and the formation of a true creative teacher by means of practical activity.

Choreographic art is rightly considered an effective means of accomplishing this task, because in choreography fantasy, diversity, unpredictability play an extremely important role, since every new performance of dance, the creation of new elements of vocabulary and figures requires improvisation, creativity, freshness. Choreographic art is a plastic art, where the material is the human body itself, which, as if animated by music, sculptures aesthetically perfectly embodies in its graceful movements the harmony of the body and soul of man, its external and internal beauty.

On the basis of the analysis of psychological and pedagogical art literature, the concept is revealed and the essence of definitions of dance is determined, which allowed to define it as a spatiotemporal integrated form of art in which artistic images are created with the help of aesthetically meaningful, musically organized, rhythmically changing movements and poses. The formation of a dancer in his or her own dance language takes place in a cultural context. The education of the dance movement culture, which is made possible by creative mastering of the cultural experience of humanity in the field of choreography, is of great importance.

Key words: creativity, choreographic art, dance, creative individuality, personality.
Постановка проблеми у загальному вигляді. Світ навколо нас постійно розвивається й оновлюється, адже все перебуває у невпинному русі. Це незаперечні закони розвитку природи і людства, яких повинна дотримуватися кожна людина, адже рух і розвиток і $є$ саме життя. Сучасне соціальне середовище вимагає людей, котрі активно мислять і діють, швидко реагують на різноманітні зміни, легко вирішують нестандартні ситуації. Нашому суспільству про- сто необхідні креативні особистості 3 яскраво вираженою творчою індивідуальністю. Кожна така особистість фрормується у процесі навчання і виховання, зокрема у вищому навчальному закладі. Питання творчості у своїх працях розглядають багато вчених, зокрема О. Брушлінський, О. Васильєва, О. Губенко, Ю. Кулюткін, С. Сисоєва та ін. Дослідженням проблеми вияву творчої індивідуальності займалися В. Кан-Калік, А. Макаренко, В. Моляко, Н. Нікандров, В. Поно- 
марьов, В. Сластьонін, В. Сухомлинський та ін. Як зазначає Л. Бірюкова, вчені одностайні в тому, що розв'язання цієї проблеми - одне 3 головних завдань професійної підготовки майбутніх кадрів, адже, розвиваючи творчу індивідуальність студента, ми фрормуємо потребу в самоосвіті як якості особистості, що спрямовує до оволодіння майстерністю педагогічної профресії [2, с. 249]. О. Таранцева у своєму дослідженні вказує на те, що пріоритетним завданням вищих навчальних закладів педагогічного спрямування на етапі інтеграції України до європейського освітнього простору стає підготовка вчителя нової генерації. Позашкільним закладам освіти потрібні педагоги, котрі уособлюють яскраву творчу індивідуальність, здатну забезпечити максимальну реалізацію творчого потенціалу вихованця, а це характерно для вчителів мистецьких дисциплін, зокрема вчителів хореографії [5, с. 18]. Розвиток творчої індивідуальності практично неможливий без самої творчості. Для того, щоб людина набула певних навичок, сорормувала в собі певні якості, набула певних практичних умінь, необхідна постійна і систематична творча діяльність.

Ефективним засобом реалізації цього завдання правомірно вважається хореографрічне мистецтво, адже в хореографрії франтазія, різноманітність, непередбачуваність відіграють винятково важливу роль, оскільки кожне нове виконання танцю, створення нових елементів лексики та фрігур вимагає імпровізаційності, творчості, свіжості.

Танець $€$ пластично-просторово-часовим видом мистецтва, у якому художні образи створюються за допомогою естетично забарвлених, музично організованих, ритмічно змінюваних рухів і поз людського тіла. Його творчий потенціал генетично закладений вже у самій його природі [7, с. 3]. Так, танцювальні рухи з прадавніх часів слугували індивідуальним художнім вираженням сприйняття виконавцем навколишнього світу. За допомогою різноманітних поз і міміки танцюристи висловлювали свої почуття, емоції та думки.

Танець дозволяє створити комфортне навчальне і комунікативне середовище, адже його структура і чіткий малюнок фрормують зовнішні опори для поведінки людини. Створюючи емоційну рівновагу в групі, танець заспокоює, «збирає» виконавців, полегшує налагодження стосунків між ними. Навіть дуже розгальмовані люди, потрапляючи до його атмосорери, починають будувати власну поведінку відповідно до його правил, виконують загальні для всієї групи рухи. Це зумовлюється тим, що у процесі танцювання виконавці, хоча й імпровізують під музику, виявляючи у пластичних рухах свої франтазії й почуття, все ж підпорядковуються чіткій ритмічній і композиційній структурі танцю, яка організує їх, уможливлює розуміння комунікативних сенсів.
Аналіз останніх досліджень і публікацій. Творчі можливості цього виду мистецтва були високо оцінені видатними хореографами та педагогами, котрі створили власні хореограсрічно-педагогічні системи: В. Верховинцем, М. Вігман, М. Грехем, А. Дункан, Е. Жак-Далькрозом, Р. Лабаном, У. Лембом та ін.

На основі творчого використання танцю був створений новий напрям арт-терапії - танцювальна терапія, яскравими представниками якого стали Г. Аммон, М. Вайтхауз, Е. Грьонлюнд, Л. Еспенак, Л. Мова, Н. Оганесян, М. Чейз, Т. Шкурко, Т. Шуп та ін.

Значний внесок у теорію та практику творчого розвитку особистості засобами хореограсрічного мистецтва зробили українські вчені К. Василенко, В. Куплених, В. Пастух, Ю. Станішевський, Б. Стасько, О. Таранцева та ін.

Виділення невирішених раніше частин загальної проблеми. Водночас слід зазначити, що, незважаючи на досить глибоку розробленість у працях цих науковців різноманітних аспектів проблеми творчого застосування танцю з педагогічною та лікувальною метою, поза увагою дослідників залишилися питання розвитку творчої індивідуальності особистості засобами хореографії.

Мета статті. Для того, щоб виявити специфріку реалізації креативних можливостей танцювального мистецтва, необхідно, передусім, визначити зміст цього поняття.

Сьогодні у мистецькій практиці термін «танцювальне мистецтво» вживається паралельно 3 термінами «хореографрія» та «хореографрічне мистецтво» і нерідко підмінюється ними. Проте, незважаючи на генетичну близькість їх змісту, ці поняття не тотожні. Узагальнення наявних у сучасній мистецтвознавчій і довідковій літературі дефініцій танцю дозволило визначити його як просторовочасовий інтегрований вид мистецтва, в якому художні образи створюються за допомогою естетично значущих, музично організованих, ритмічно змінюваних рухів і поз людського тіла. [3, с. 180].

Термін «хореографрія» 3'явився у ході історичного розвитку танцювального мистецтва дещо пізніше за термін «танець». Він має декілька значень:

- запис танцювальних рухів за допомогою особливої системи умовних позначень;

- мистецтво композиції та постановки танців і балетних спектаклів;

- увесь обсяг танцювальних елементів, що входять до певного танцю чи балетної вистави;

- поняття, яке охоплює всі види танцювального мистецтва [7, с. 18].

Виклад основного матеріалу. Досліджуючи танець, науковці та мистецтвознавці аналізують його з різних позицій: естетичної, історико-культурологічної, соціологічної, психологічної, терапевтичної, педагогічної тощо. 
Значна кількість праць вітчизняних і зарубіжних вчених присвячена проблемі походження й. розвитку танцювального мистецтва, його основних фрорм і жанрів.

Ряд дослідників пов'язує появу танцю з обрядовими дійствами первісної людини (Р. Краус, Л. Морган, Г. Добровольська). Інші вважають, що він народився як природна потреба людини у русі, викликана її емоціями (А. Хаскелл, А. Меррей) $[1$, c. 26$]$.

Біологічна теорія походження танцю вбачає його витоки у любовних танках птахів і звірів, а також у наслідуванні їхніх рухів і звичок людиною.

Релігійна теорія ґрунтується на розумінні його як божественного акту творення світу та засобу спілкування людини з вищими силами. Будучи узаконеним елементом культу ряду протестантських церков, танцювальні рухи слугують для об'єднання громади у вираженні релігійних почуттів.

Космологічна теорія виникнення танцю (Х. Елліс) базується на трактуванні його як провідника ритмів та енергії Космосу, що забезпечують можливість утворення Всесвіту, й розумінні фрізичної та біологічної фрорм життя як танцювального руху, підпорядкованого всезагальному ритму, заданому космічними впливами. Свій початок ця теорія отримала у вченні піфагорійців, котрі доводили здатність ритмів і мелодій танцю перетворювати Хаос на Космос, забезпечуючи гармонійний розвиток природи й усього живого на Землі [8, с. 19].

Комунікативна теорія походження танцю (А. Ломакс) доводить, що останній виник внаслідок нерозвиненості мовлення первісних людей як засіб, який уможливив їхнє спілкування за допомогою жестів і міміки. Таким чином, танець $€$ моделлю життєво необхідного комунікативного зв'язку, котра фокусує у собі найбільш поширені моторно-рухові зразки, що найчастіше і найбільш успішно використовувалися у житті людей певної культурної спільноти.

Прихильниками соціологічної теорії походження танцю $є$ К. Бюхер і Г. Плеханов. Вони пов'язують виникнення танцю як виду мистецтва з розвитком форм господарства та способів виробництва первісної людини.

М. Каган, А. Столяр і С. Замятин досліджують історію зародження i розвитку танцювального мистецтва з позицій естетичної теорії. Вони вбачають витоки танцю у прадавньому синкретичному художньому дійстві.

Водночас серед усіх описаних вище художніх засобів танець вирізняється тим, що є складним видом мистецтва, який інтегрує у собі: художній рух (кінестетику, міміку й пантоміміку); музику (вокальний та інструментальний; мелодичний і ритмічний супровід); елементи образотворчого мистецтва (композицію, орнаментальний малюнок танцю, костюми, маски, декорації) та театралізації (розподіл танцювальних партій; сюжетну лінію та драматургію тощо) [8, с. 22].

Художній образ, що лежить в основі танцю, розкриває, з одного боку, об'єктивну картину дійсності, а 3 іншого - суб'єктивне, індивідуальне бачення їі виконавцем, тобто створюється у процесі художнього узагальнення через індивідуально неповторну, емоційно насичену форму. Адже, як справедливо стверджувала Л. Еспенак, рух без почуттєвого вираження $є$ усього лише фрізичною вправою. Водночас через тренування моторики стимулюється й відбувається психологічний розвиток особистості, гармонізація тіла, почуття та інтелекту. Оскільки творча індивідуальність становить гармонійну єдність усіх цих якостей, танець $є$ ефективним засобом її фрормування.

Айседора Дункан, видатна танцівниця, поставила головні завдання хореографра: зробити тіло слухняним інструментом передачі внутрішнього стану й емоцій особистості та водночас дати людині відчуття «м'язевої радості» у процесі виконання танцю; гармонізувати її тіло й душу у танцювальному русі; навчити її вільно володіти мовою тіла у процесі хореографічної імпровізації, самостверджуватися у танці, виявляючи свою творчу волю і неповторну індивідуальність [7, с. 15].

Розв'язання цих завдань уможливлюється завдяки потужному креативному потенціалу хореограсрічного мистецтва.

Останній виявляється у здатності танцю засобом впливу на естетичні почуття розвивати в особистості художні та творчі здібності; збуджувати їі франтазію та стимулювати пошук власних хореографрічних засобів ії̈ втілення; заохочувати творчу активність людини, викликати в неї бажання експериментувати зі своїм тілом, імпровізувати на задані хореографрічні теми; знімати м'язове, емоційне та психічне напруження і завдяки цьому отримувати сенсорне задоволення від відчуття свого власного тіла, його гнучкості та краси.

У зв'язку з цим важливо пам'ятати, що танцювальний рух, який несе в собі естетичне начало, неможливо нав'язати ззовні або засвоїти лише механічно (технічно). Він повинен виходити «від танцюриста», від його власної людської індивідуальності, від форми його тіла, фрігури, статури тощо.

Вільні рухи Айседори Дункан перейняв і впровадив до своєї системи ритмічного виховання Еміль Жак-Жалькроз. Він розробив і вперше в хореографрічній педагогіці застосував техніку аритмі (arytmie), яка, на його переконання, «збудовує місток» між музикою та індивідуальністю. Згідно 3 Е. Жак-Далькрозом, не існує музики та індивіда окремо, якщо $є$ спільний рух. Ритміка повинна відчуватися свідомо, через м'язові рухи, й передавати музичний ритм. Природні м'язові ритмічні вібрації видатний педагог вважав дуже індивідуальними і говорив, що вони співіснують, як живі. 
Значний внесок в обґрунтування креативного потенціалу хореографрічного мистецтва зробила Мері Вігман, котра була переконана, що танець $€$ головним з усіх мистецтв, оскільки засобом усього тіла він відображає внутрішню символічну форму розвитку. Розроблені нею креативні вправи полягають у тому, що дозволяють почуттям вільно вийти назовні. Тому метою М. Вігман було не створення нових танців, а пошук таких рухів, що відкривають і розвивають людей. Ці хореографрічні рухи нині широко використовуються у танцювальній психотерапії.

Багато нового вніс у танець Рудольф Лабан. Він наголошував, що рухи впливають не лише на фрізичний, але й на психічний стан людини. Вважаючи танець природною формою чуттєвого вираження людини, він вбачав призначення науки про тілесні рухи в тому, щоб активізувати їі творчу уяву й вивчати людські звичаї та виразність. Розроблена ним рухова система підходить і тим, хто професійно не займається танцями, зокрема вона буде дуже корисною у процесі розвитку творчої індивідуальності майбутніх педагогів професійного навчання [4, с. 473].

У педагогічно-хореографрічній підготовці майбутніх педагогів доцільно використовувати також вчення Р. Лабана, М. Вігман про ритм і динаміку, згідно 3 яким індивідуальність людини виявляється в тому, що вона має свій індивідуальний ритм і динаміку руху, яка їй найбільше підходить. Об'єднання у русі в одну систему фізичних якостей, почуттів і розуму, хаосу й порядку дозволяє оцінити характер та індивідуальні особливості людини.

Пропоновані студентам танцювальні вправи можуть мати найрізноманітніший зміст і форму: спонтанний танець, парний чи груповий структурований танець, танець-самовираження, танцювальні ігри, пантоміми, імпровізації, танцювальноекспресивний тренінг та ін. Усі вони спрямовуються на висловлення у виразному емоційному русі:

- своїх внутрішніх відчуттів, що допомагають зрозуміти себе і свій внутрішній стан;

- емоційного стану партнера, що дозволяє краще зрозуміти його;

- спільного емоційного переживання від взаємодії партнерів у танці; відчуття «м'язових радощів»;

- своїх танцювальних франтазій тощо [3, с. 181].

Хореограсрічний навчально-виховний процес $\epsilon$ важливою складовою частиною загальної освіти, оскільки справляє величезний вплив на фрормування індивідуальності вихованця. Дослідниця креативного потенціалу хореограсрії Т. Морозовська вбачає мету занять хореографією у навчанні учнів сприймати та розуміти мистецтво, розвитку їхніх здібностей і здатності до творчості, збагаченні їхнього чуттєвого сприйняття себе та навколишнього світу через відчуття свого тіла, розши- рення його фрізичних можливостей; фрормуванні необхідних соціальних навичок тощо [6, с. 152].

Аналізуючи поширену практику хореографрічної підготовки, Т. Морозовська відзначає ії репродуктивний характер, що виявляється у спрямуванні мети навчальної роботи лише на складання, розучування та виконання танців, засвоєння необхідних для цього умінь і навичок. За такого підходу учасники танцювального колективу виступають як своєрідний матеріал для діяльності викладачахореографа. Знання та навички, отримані ними під час занять, мають прикладний характер, хоча вважається, що результатом хореографрічно-педагогічної діяльності $€$ виховання тіла та розуму учасників хореографічного колективу.

Але ж сьогодні, коли утверджується нова, гуманістична парадигма освіти, такий підхід є, вочевидь, застарілим, - вважає Т. Морозовська. Тому в хореографічному навчанні увага педагога повинна зосереджуватися, на її думку, не стільки на розучуванні та виконанні художнього твору (хоча це також, безсумнівно, важливо), скільки (і насамперед) на «можливості змінювання індивіда» (В. Біблер), розвитку в людини прагнення до самовдосконалення [8, с. 16].

Повністю поділяючи цю позицію фрілософа, T. Морозовська розглядає «можливість змінювання» як формування людини, здатної до навчання себе. У цьому процесі, на її переконання, найбільш повною мірою реалізуються психологічні механізми впливу танцю на розвиток творчої індивідуальності. За такого підходу створення танцю як художнього твору неначе відступає на другий план, отримує прикладний характер. Викладачхореограф поступається місцем викладачеві-вчителю. Внутрішній діалог голосів учителя і хореографра у свідомості викладача виступає як один із механізмів його творчості. Він звертає увагу не лише на те, що можна зробити з танцівника зараз, але й на подальший вплив занять на його розвиток. Необхідною умовою занять хореографрією виступає його радість від танцювальної творчості. Інакше, на переконання Т. Морозовської, відбувається зміщення його мотивації, переоцінка найважливіших духовних цінностей і замість гармонійно розвиненої особистості постає духовно і фрізично скалічена людина.

Танцювальна техніка виступає тут як своєрідна мова танцю, усвідомлення важливості опанування якої випливає із завдань, поставлених перед дітьми у ході уроку. Прийняті у хореограсрії й опановані дитиною положення рук, ніг, голови, корпусу; танцювальні рухи, сталі традиції розуміння цих рухів не повинні знімати необхідності побудови особистої мови рухів, особистих відкриттів у танці. Коли людина танцює для себе, вона зазвичай рухається виразно, невимушено, граційно. На заняттях із хореографрії важливо зберегти цю при- 
родну єдність, виразність рухів. Тому викладач має бути тактовним і обережним, нічого не нав'язувати танцівникам, надавати їм можливість вільно виявляти свою ініціативу, використовуючи танцювальну імпровізацію [4, с. 473]. Але важливо, щоб фрормування в танцюриста своєї танцювальної мови відбувалося в культурному контексті, щоб створення танцю не обмежувалося лише вільною імпровізацією, спонтанним втіленням думок і почуттів у танцювальних рухах. Велике значення має виховання культури танцювальних рухів, що уможливлюється шляхом творчого опанування культурного досвіду людства у галузі хореографії.

Висновки. Таким чином, розвивальна функція хореографрічного мистецтва полягає у його спроможності забезпечувати гармонію фрізичного і духовного, естетичного, художнього та творчого розвитку майбутнього педагога професійного навчання; сприяти вдосконаленню його сутнісних сил, творчих якостей і здібностей, зростанню внутрішніх потенціалів, розвиткові пізнавальної активності й емоційної чутливості, естетичних потреб і смаків, стимулюванні прагнення до самовдосконалення.

Крім того, танець сприяє фрізичному розвиткові студентів, зміцнює їхній опорно-руховий апарат і покращує поставу, фрормує їхні художньо-пластичні здібності. Це надає йому винятково важливого значення в умовах сучасного інфрормаційного суспільства, яке дедалі більше «прив'язує» молодь до комп'ютера, спричиняючи її гіподинамію та фрізичну недорозвиненість. Впровадження танцю до процесу майбутніх педагогів наряду із заняттями спортом, фрізкультурою, аеробікою чи бойовим гопаком сприятимуть оздоровленню студентської молоді, а також естетизації навчальновиховного процесу сучасних професійно-педагогічних закладів освіти.

\section{БІБЛІОГРАФІЧНИЙ СПИСОК:}

1. Бех І.Д. Виховання особистості : у 2 кн. Кн. 1: Особистісно-орієнтований підхід: теоретико-технологічні засади. Київ : Либідь, 2003. 280 с.

2. Бірюкова Л.А. Педагогічна проблеми розвитку творчої індивідуальності вчителя музики. Педагогічні науки: теорія, історія, інноваційні технології. 2009. № 2. C. $249-256$.

3. Поклад І.М. Деякі аспекти виховання особистості засобами хореограсрічного мистецтва. матеріали до українського мистецтвознавства (на пошану А.І. Мухи) : збірник наукових праць НАН України та Інституту мистецтвознавства, фольклористики та етнографії ім. М.Т. Рильського за матеріалами Міжнародної наукової конференції «Україна на межі тисячоліть: етнос, нація, культура». Київ, 2003. Вип. 3. С. 179-183.

4. Поклад І.М. Розвиток творчого потенціалу особистості в навчально-виховному процесі. Проблеми гуманізації навчання та виховання у вищому закладі освіти : Матеріали третіх Ірпінських міжнародних науково-педагогічних читань. Ірпінь : Національна Академія ДПС України, 2005. С. 471-473.

5. Таранцева О.О. Формування фрахових умінь майбутніх вчителів хореографії засобами українського народного танцю : автореф. дис. ... канд. пед. наук : 13.00.04. Київ, 2002. 22 с.

6. Тарасюк А.М. Професійна підготовка майбутніх учителів хореографії до роботи у позашкільних закладах освіти. Педагогічний альманах : збірник наукових праць / редкол. В.В. Кузьменко та ін. Херсон : РІПО, 2012. Вип. 13. 303 с.

7. Шариков Д.І. Теорія, історія та практика сучасної хореографії : монографрія. Київ : КиМУ, 2010. С. 26.

8. Фриз П.І. Зміст, фрорма і сутність хореографрічної культури та її вплив на творчий розвиток особистості дитини. Музикознавчі студії. Hayкові збірки ЛДМА імені М.В. Лисенка. Львів. 2007. Вип. 16. С. 15-23. 